\title{
SOME RECENT SASKATCHEWAN RACCOON RECORDS
}

\author{
by Wayne C. Harris, Raymore
}

The range of the Raccoon (Procyon lotor) was until recently thought to extend only to the southern portion of the province. Harvey Beck ( $A$ guide to Saskatchewan mammals, S. N.H.S. Spec. Publ. No. 1, 1958) gives records from Estevan, Regina, Carlyle, Disley, Kelster, Meadow Lake, Moose Mountain, North Portal, Vantage and Wauchope. The Meadow Lake report is the only record north of the Qu'Appelle River Valley, thus leaving a gap of approximately 300 miles in which there are no records.

The following records partially fill this gap:

Norman B. Beug, Raymore, in the fall of 1967 (thought to have been September although the exact date is unknown) sighted a Raccoon eight miles south and one mile east of Raymore as it ran through the headlights of a truck.
Dave Gray, Wildlife Research Branch, Department of Natural Resources, Saskatoon, found a roadkilled Raccoon 10 miles south of Saskatoon on highway No. 11 in June 1969. This individual was a male and was thought to have been an adult.

On September 5, 1969, at 8:35 p.m., J. B. Gollop and Hugh Boyd, Canadian Wildlife Service, Saskatoon, saw a single Raccoon crossing a road two miles east of Strehlow (approximately 15 miles SSE of Saskatoon).

The most recent record is from an area seven and one-half miles west of Semans. On September 12, 1971 the writer picked up two individuals which had been hit by vehicles on highway No. 15. The two animals were within 25 yards of one another on the road. One of these was a female, the other a male; the closeness of the kills suggests that they were probably a pair.

\section{DIE-OFF OF AMBYSTOMA TIGRINUM IN A PRAIRIE POND}

\section{by E. A. Driver, Canadian Wildlife Service, Saskatoon}

One hundred and fifty-two dead larval tiger salamanders, Ambystoma tigrinum, from 9 to 13 centimeters (approximately four to five inches) in length were counted in a 0.19 hectare ( 0.5 acre) pond near Floral, Saskatchewan $\left(52^{\circ} 02^{\prime} \mathrm{N}, 106^{\circ} 31^{\prime} \mathrm{W}\right)$, in midafternoon on July 10, 1970. No dead adults were observed. Several live larvae were seen on the morning of July 10.

The pond had a maximum depth of 62 centimeters (24 inches) and was moderately fresh, having a total dissolved solid concentration of 520 parts per million. The water was slightly brown in colour ( 50 Hazen units) and weakly alkaline, $\mathrm{pH}$ 7.6. No dissolved oxygen readings were taken on July 10. Emergent vegetation consisted of hard stem bulrush (Scirpus acutus), wh it e to p (Scolochloa festucacea), water parsnip (Sium suave) anu spike rush (Eleocharis). Aquatic macrophytes included ivy-leaf duckweed (Lemna trisulca), water milfoil ( $M y$ riophyllum exalbescens) and water starwort (Callitriche). Neither green nor blue-green algae bloom occurred in this pond in 1970 .

The counts included all salamanders on the substrate from the pond edge to a depth of 30 centimeters (one foot). This area represents $35 \%$ of the surface area of the pond. Assuming a uniform distribution of larval salamanders, an estimate of the total population was 434 or 0.23 salamanders per square ineter of substrate.

Three specimens were submitted to 
Dr. G. Wobeser, Department of Veterinary Pathology, University of Saskatchewan, Saskatoon, for examination. Initial examination conducted July 10 was followed by histopathological examination and the final report was submitted to me January 13, 1971. It stated that the tiger salamanders died from anoxia, lack of oxygen. The diagnosis supported my field observations of larval salamanders in a stressed condition surfacing for air on the morning of July 10.

Although dissolved oxygen was not measured, an oxygen deficiency probably occurred. For several days preceding the die-off, light winds, six to sixteen kilometers per hour (four to ten $\mathrm{mpn}$ ) and high water tempera- tures, 20 to $24^{\circ} \mathrm{C}$, were recorded. These conditions tend to limit dissolved oxygen levels because oxygen mixing is minimal at low wind speeds and the solubility of oxygen in water drops with an increase in water temperature. These factors, coupled with the oxygen uptake of water milfoil and water starwort at night, provide conditions conducive to a serious reduction in oxygen levels.

Dead adults of $A$. tigrinum were noted at several other ponds within 1.6 kilometers (one mile) of the above mentioned pond the following week.

I wish to thank C. A. Matthews, Canadian Wildlife Service, and D. W. Matheson for their assistance with the field count.

\section{A CHECK-LIST OF ALGAE IN WASCANA LAKE}

\section{by M. V. S. Raju, D. Young and J. E. Hines, Biology Department University of Saskatchewan, Regina}

It is well known that freshwater lakes undergo eutrophication, an aging process brought about by the interactions of a variety of physico-chemical and biological factors. Eutrophic lakes are characterized by a richness in nutrients and aquatic organisms such as algae; indeed in an extremely eutrophied laize one or a few species of algae may multiply to such a degree that virtually all other organisms are excluded. Such unusual abundance of one or a few algae in a lake is usually termed as an algal bloom and often results in the formation of surface scum such as that seen in Wascana and the Qu'Appelle lakes during the summer. When algal blooms are aesthetically or economically undesirable we commonly, although somewhat crudely, say that the lake is "polluted."

In some parts of Wascana lake a flagellate alga, Euglena, is known to form blooms and an account of this has already been published (Blue Jay, $28(1): 50-53,1970)$. An examination of water samples collected from different localities of Wascana Lake revealed a wide variety of algae, a few of which were abundant and tended to form blooms. To have a better under- standing of the mechanisms of algal blooms and also of the inter-relationships between the algae that produce blooms and the ones that do not, an attempt was made to identify systematically the algal flora of Wascana Lake. Consequently, water samples were obtained twice weekly from selected localities of the lake during the months of July and August of 1970. Similar studies were made of water samples collected at irregular intervals from Wascana Lake in June, July, August and the early part of September of 1971 . The check-list prnvided at the conclusion of this article includes all of the algal genera identified. The relative abundance of each genus is also indicated. No attempt was made, however, to identify their species. This check-list of the algae of Wascana Lake is given here with the hope that it will be useful in future investigations of algal blooms in Wascana Lake. Those algae that produce blooms will be discussed in a later article.

Part of this investigation was supported by a financial grant from Labbatt's Brewery of Canada through Pollution Probe, University of Saskatchewan, Regina Campus. 